\title{
Upaya Meningkatkan Minat Belajar Ekonomi Menggunakan Media Bahan Ajar Pada Siswa Kelas XI MA Al-Khairaat Buntulia
}

\author{
Fathan Lasiki \\ Guru MA Al-Khairaat Buntulia
}

\author{
Received: 13 August 2021; Revised: 02 October 2021; Accepted: 14 December 2021 \\ DOI: http://dx.doi.org/10.37905/aksara.8.1.389-394.2022
}

\begin{abstract}
Abstrak
Metode yang digunakan dalam penelitian ini adalah penelitian tindakan kelas yaitu penelitian terhadap tindakan yang dilakukan di kelas yang bertujuan untuk memperbaiki dan meningkatkan mutu pembelajaran. Dalam penelitian ini, tindakan kelas yang diteliti adalah penggunaan kisah sukses pelaku ekonomi sebagai media ajar untuk meningkatkan minat siswa belajar ekonomi. Model penelitian yang digunakan adalah model penelitian Kurt Lewin yang terdiri dari empat tahapan yaitu perencanaan, tindakan, pengamatan dan refeleksi.

Berdasarkan siklus tindakan yang dilakukan siklus I dan siklus II, peneliti dan kolaborator menyimpulkan bahwa tujuan penelitian tindakan dapat dikatakan berhasil. Berdasarkan hasil angket yang disebar pada akhir sesi siklus II, terjadi peningkatan minat siswa terhadap pelajaran ekonomi. Mayoritas siswa menyatakan berminat dan termotivasi belajar ekonomi.

Dari hasil penelitian tindakan kelas yang bertujuan untuk mengetahui efektifitas penggunaan kisah sukses pelaku ekonomi dalam upaya meningkatkan minat siswa belajar ekonomi, peneliti mengambil kesimpulan sebagai berikut: Penggunaan kisah sukses pelaku ekonomi untuk meningkatkan minat siswa belajar ekonomi bisa dikatakan berhasil. Ditinjau dari respon siswa terhadap pelajaran ekonomi, terjadi peningkatan jumlah siswa yang berpendapat bahwa pelajaran ekonomi menarik yaitu dari sebelumnya 6 $\%$ menjadi $63 \%$. Demikian juga $97 \%$ siswa menyatakan berminat belajar ekonomi dan $86 \%$ menyatakan termotivasi belajar ekonomi setelah melakukan pembelajaran ekonomi menggunakan kisah sukses pelaku ekonomi. Penggunaan kisah sukses pelaku ekonomi apalagi pelaku ekonomi yang memulai usahanya dari usaha kecil hingga sukses tepat digunakan untuk membangkitkan minat dan motivasi siswa belajar ekonomi. Bahwa belajar ekonomi tidak sekedar untuk mengetahui tetapi lebih dari itu untuk menerapkan dalam kehidupan sehari-hari dengan berperilaku ekonomis.
\end{abstract}

Kata kunci: Minat belajar, media bahan ajar, ekonomi

\section{PENDAHULUAN}

Selain intelegensi, minat merupakan faktor psikologis yang mempengaruhi hasil belajar siswa (Syah, 2002). Hal itu karena minat terkait erat dengan motivasi. Minat terhadap pelajaran tertentu akan memotivasi siswa lebih tekun mempelajari bidang studi yang diminatinya tersebut. Minat belajar tidak saja penting bagi siswa namun juga menjadi masalah penting yang harus dihadapi guru. Keberhasilan atau kegagalan guru dalam membangkitkan minat belajar siswa sangat berpengaruh terhadap pencapaian kompetensi hasil belajar yang dikehendaki. Tanpa adanya minat siswa terhadap mata pelajaran yang diajarkan, maka guru harus bersiap mengalami kekecewaan, frustasi dan makan hati ketika mengajar. Di lain pihak, hal yang sama juga dialami oleh siswa yaitu sikap apatis, pasif, tidak memahami materi dan pada akhirnya hanya berorientasi pada nilai.

Mata pelajaran ekonomi bukan mata pelajaran yang sama sekali baru diajarkan pada tingkat sekolah menengah atas (SMA/MA). Siswa kelas XI di tingkat SMA/MA sudah memiliki pengalaman belajar ekonomi ketika mereka masih duduk di bangku 
SMP/MTs. Pengalaman belajar sebelumnya dapat mempengaruhi minat belajar siswa (Hurlock, 1980). Berdasarkan wawancara singkat, mayoritas siswa klas XI menganggap bahwa mata pelajaran ekonomi adalah mata pelajaran yang tidak menarik atau biasabiasa saja. Faktor-faktor yang menjadi penyebab diantaranya adalah mata pelajaran ekonomi dianggap sulit karena banyak menghitung dan menghafal. Selain itu, faktor guru yang kurang mengembangkan metode pembelajaran ekonomi juga dianggap sebagai faktor yang mempengaruhi minat siswa terhadap mata pelajaran ekonomi. Memperhatikan kondisi tersebut, guru mata pelajaran ekonomi di klas X harus berupaya sedemikian rupa mengembangkan metode pembelajaran sehingga minat siswa belajar ekonomi tinggi.

Tujuan umum pendidikan ekonomi di SMA/MA adalah agar peserta didik dapat merekam peristiwa ekonomi yang terjadi disekitar lingkungannya dan mengambil manfaat untuk kehidupannya yang lebih baik (KTSP 2006). Hal itu sesuai dengan pengertian ilmu ekonomi yaitu bidang studi tentang umat manusia dalam kehidupan sehari-sehari (Mankiw, 2007). Dengan demikian, karakteristik ilmu ekonomi adalah sangat erat dengan kehidupan sehari-hari. Atau dapat dikatakan bahwa sebagian besar sumber segala permasalahan di dunia ini adalah masalah ekonomi.

Dengan karakteristik ilmu ekonomi yang 'membumi' tersebut, semestinya pelajaran ekonomi adalah pelajaran yang menarik. Pelajaran ekonomi adalah pelajaran tentang permasalahan hidup sehari-hari yang pasti dialami oleh setiap manusia selama hidup di dunia. Pelaku-pelaku ekonomi baik konsumen, produsen, maupun distributor bertebaran di sekeliling kita menjadi buku terbuka yang siap untuk dipelajari. Kisah pelaku ekonomi yang sukses maupun yang gagal dapat menjadi contoh bagaimana penerapan suatu teori ekonomi dalam kehidupan nyata. Penggunaan kisah sukses pelaku ekonomi dalam pembelajaran ekonomi diharapkan dapat membangkitkan minat siswa belajar ekonomi. Lebih lanjut diharapkan dapat memotivasi siswa berperilaku ekonomis dalam menentukan pilihan-pilihan terbaik diantara keterbatasan sumber daya yang dimiliki.

Penggunaan kisah sukses pelaku ekonomi dalam pembelajaran ekonomi adalah salah satu upaya mengembangkan pembelajaran aktif, kreatif dan menyenangkan (PAKEM). Juga, metode ini merupakan upaya pembelajaran berbasis kontekstual (contextual learning/CTL) sehingga mata pelajaran ekonomi tidak sekedar pembahasan materi. Kedua metode tersebut disinyalir cocok bagi paradigma pendidikan yang berpusat pada siswa (student center learning). Oleh karena itu, penelitian ini bertujuan untuk meneliti efektifitas penggunaan kisah sukses pelaku ekonomi sebagai media ajar untuk meningkatkan minat siswa belajar ekonomi.

\section{METODE PENELITIAN}

Metode yang digunakan dalam penelitian ini adalah penelitian tindakan kelas (classroom action research) yaitu penelitian terhadap tindakan yang dilakukan di kelas yang bertujuan untuk memperbaiki dan meningkatkan mutu pembelajaran. Dalam penelitian ini, tindakan kelas yang diteliti adalah penggunaan kisah sukses pelaku ekonomi sebagai media ajar untuk meningkatkan minat siswa belajar ekonomi.

Model penelitian yang digunakan adalah model penelitian Kurt Lewin yang terdiri dari empat tahapan yaitu perencanaan, tindakan, pengamatan dan refeleksi. 
Subyek penelitian adalah siswa Kelas XI MA Al Khairaat Buntulia yang mengikuti pembelajaran ekonomi menggunakan kisah sukses pelaku ekonomi sebagai media ajar.

Dalam penelitian ini, peneliti bertindak sebagi perancang dan pelaksana kegiatan. Peneliti membuat perencanaan kegiatan, melaksanakan kegiatan, melakukan pengamatan, mengumpulkan dan menganalisis data, serta melaporkan hasil penelitian. Instrumen pengumpulan data yang digunakan adalah kuisioner untuk mengetahui minat siswa belajar ekonomi. Instrumen ini dibuat dengan model pertanyaan berstruktur dan didesain sama sekali tanpa identitas subyek penelitian untuk menghindari bias data penelitian. Data-data pendukung lainnya dikumpulkan melalui wawancara, pengamatan dan dokumentasi lain yang diperlukan.

Untuk memperoleh data yang valid yaitu data yang obyektif, sahih dan handal dalam penelitian ini digunakan teknik triangulasi yaitu menggali data dari sumber yang sama dengan cara yang berbeda. Dalam hal ini, minat siswa belajar ekonomi diperoleh dari menyebarkan angket, wawancara dan respon tertulis siswa tentang minat belajar ekonomi. Demikian juga catatan dari kolaborator digunakan sebagai data pembanding untuk mengetahui hasil penelitian tindakan kelas.

\section{HASIL DAN PEMBAHASAN}

Berdasarkan siklus tindakan yang dilakukan siklus I dan siklus II, peneliti dan kolaborator menyimpulkan bahwa tujuan penelitian tindakan dapat dikatakan berhasil. Berdasarkan hasil angket yang disebar pada akhir sesi siklus II, terjadi peningkatan minat siswa terhadap pelajaran ekonomi. Mayoritas siswa menyatakan berminat dan termotivasi belajar ekonomi. Hasil selengkapnya dapat dilihat dalam tabel berikut.

Tabel 1. Minat dan Motivasi Siswa Belajar Ekonomi setelah Tindakan

\begin{tabular}{llllll}
\hline \multirow{2}{*}{ Pertanyaan } & \multicolumn{3}{l}{ Ya } & \multicolumn{3}{c}{ Tidak } \\
\cline { 3 - 6 } & Jumlah & $\%$ & Jumlah & $\%$ \\
\hline $\begin{array}{l}\text { 1.Apakah Anda berminat belajar } \\
\text { ekonomi, setelah mengetahui kisah } \\
\text { sukses pelaku ekonomi? }\end{array}$ & 34 & $97 \%$ & 1 & $3 \%$ \\
\hline $\begin{array}{l}\text { 2.Apakah kisah sukses pelaku ekonomi } \\
\text { yang digunakan dalam pembelajaran } \\
\text { ekonomi memotivasi Anda untuk } \\
\text { belajar ekonomi? }\end{array}$ & & $86 \%$ & 5 & $14 \%$ \\
\hline
\end{tabular}

Demikian juga terjadi peningkatan respon siswa terhadap pelajaran ekonomi dari sebelumnya tidak menarik dan biasa-biasa saja menjadi pelajaran yang menarik. Perbandingan respon siswa terhadap pelajaran ekonomi sebelum dan sesudah tindakan sebagai berikut. 
Tabel 5. Respon Siswa terhadap Pelajaran Ekonomi Sebelum dan Setelah Tindakan

\begin{tabular}{lllll}
\hline \multirow{2}{*}{$\begin{array}{l}\text { Respon Siswa terhadap } \\
\text { Pelajaran Ekonomi }\end{array}$} & \multicolumn{2}{l}{ Sebelum Tindakan } & \multicolumn{2}{l}{ Setelah Tindakan } \\
\cline { 2 - 5 } & Jumlah & $\%$ & Jumlah & $\%$ \\
\hline Menarik & 2 & $6 \%$ & 22 & $63 \%$ \\
\hline Biasa-biasa & 28 & $80 \%$ & 12 & $34 \%$ \\
\hline Tidak Menarik & 5 & $14 \%$ & 1 & $3 \%$ \\
\hline Total & 35 & $100 \%$ & 35 & $100 \%$ \\
\hline
\end{tabular}

Sedangkan ditinjau dari hubungan antara penggunaan kisah sukses pelaku ekonomi sebagai media ajar dengan penguasaan materi, mayoritas siswa menyatakan bahwa metode ini memudahkan untuk memahami materi. Berikut ini tabel yang menggambarkan respon terhadap hubungan antara pemahaman materi dengan metode pembelajaran.

Tabel 6. Pemahaman Materi Siswa dengan Penggunaan Media ajar Kisah Sukses Pelaku Ekonomi

\begin{tabular}{lll}
\hline $\begin{array}{l}\text { Pemahaman Materi Siswa } \\
\begin{array}{l}\text { Penggunaan Media ajar Kisah Sukses } \\
\text { Pelaku Ekonomi }\end{array}\end{array}$ & Jumlah & $\%$ \\
\hline Memudahkan & 19 & $54 \%$ \\
\hline Biasa-biasa saja & 15 & $43 \%$ \\
\hline Tidak memahami materi & 1 & $3 \%$ \\
\hline Total & 35 & $100 \%$ \\
\hline
\end{tabular}

Dari tabel tersebut, jumlah siswa yang menganggap bahwa penggunaan kisah sukses pelaku ekonomi sebagai media ajar memudahkan memahami materi, hampir sama dengan jumlah siswa yang menyatakan biasa-biasa saja. Bahkan ada seorang siswa yang menyatakan bahwa metode ini membuatnya tidak dapat memahami materi. Hal ini, menurut peneliti harus dicermati dan ditindaklanjuti karena tujuan kognitif dari semua pembelajaran adalah pemahaman materi. Namun demikian, tujuan penelitian ini adalah untuk meningkatkan minat siswa belajar ekonomi bukan meningkatkan prestasi belajar ekonomi. Oleh karena itu indikator keberhasilan penelitian dilihat pada peningkatan minat siswa belajar ekonomi. Dari itu peneliti tidak melakukan tindakan penilaian/tes kognitif yang hasilnya berupa skor/nilai masing-masing siswa. Penilaian/evaluasi dilakukan secara lisan untuk mengetahui pemahaman materi secara umum.

\section{KESIMPULAN}

Dari hasil penelitian tindakan kelas yang bertujuan untuk mengetahui efektifitas penggunaan kisah sukses pelaku ekonomi dalam upaya meningkatkan minat siswa belajar ekonomi, peneliti mengambil kesimpulan sebagai berikut: 1) Penggunaan kisah sukses pelaku ekonomi untuk meningkatkan minat siswa belajar ekonomi bisa dikatakan berhasil. Ditinjau dari respon siswa terhadap pelajaran ekonomi, terjadi peningkatan jumlah siswa yang berpendapat bahwa pelajaran ekonomi menarik yaitu dari 
sebelumnya $6 \%$ menjadi $63 \%$. Demikian juga 97\% siswa menyatakan berminat belajar ekonomi dan 86\% menyatakan termotivasi belajar ekonomi setelah melakukan pembelajaran ekonomi menggunakan kisah sukses pelaku ekonomi. 2) Penggunaan kisah sukses pelaku ekonomi apalagi pelaku ekonomi yang memulai usahanya dari usaha kecil hingga sukses tepat digunakan untuk membangkitkan minat dan motivasi siswa belajar ekonomi. Bahwa belajar ekonomi tidak sekedar untuk mengetahui tetapi lebih dari itu untuk menerapkan dalam kehidupan sehari-hari dengan berperilaku ekonomis. 3) Minat siswa belajar ekonomi tentu dipengaruhi oleh banyak faktor, salah satunya adalah dipengaruhi oleh pemilihan media dan metode pembelajaran seperti terbukti dalam penelitian tindakan ini. 4) Penelitian tindakan kelas untuk meningkatkan minat belajar lebih tepat dilakukan pada awal-awal pertemuan. Pada pertemuanpertemuan berikutnya jika hendak dilakukan penelitian tindakan lebih tepat bertujuan untuk meningkatkan prestasi belajar.

Dari hasil penelitian yang diperoleh dari uraian, maka disampaikan saran sebagai berikut: 1) Kisah sukses pelaku ekonomi sebagai media ajar, berdasarkan penelitian ini dapat digunakan untuk meningkatkan minat siswa belajar ekonomi, namun masih perlu dilakukan penelitian lebih lanjut dan perbaikan jika kisah sukses pelaku ekonomi digunakan untuk meningkatkan prestasi belajar ekonomi. 2) Masih perlu penelitian tindakan kelas lanjutan dengan subyek penelitian yang lebih banyak untuk lebih meyakinkan bahwa minat siswa belajar ekonomi dipengaruhi oleh penggunaan kisah sukses pelaku ekonomi. 3) Untuk menjaga minat belajar ekonomi khususnya dan pelajara-pelajaran IPS lain yang cenderung diasumsikan dengan hafalan, guru perlu melakukan variasi dalam media dan metode pembelajaran.

\section{DAFTAR PUSTAKA}

Anies. 2003. Problem Based Learning. Artikel. Tersedia padahttp://www.suaramerdeka.com/harian/0304/28/kha2.htm. Diunduh tanggal11 Januari 2010.

Hanafiah. 2009. Motivasi Belajar Siswa. Artikel. Tersedia padahttp://www.suaramerdeka.com/harian/0907/34/kha4.htm. Diunduh tanggal11 Januari 2010.

Harun Supriatna. 2009. Minat Belajar Siswa. Artikel. Tersedia pada http://www.asbabulismu.blogspot.com/2009/04/minatbelajar.html. Diunduh tanggal 10 Maret 2010 pukul 10.59 WIB.

Ibrahim, Muslimin, dkk. 2000. Pengajaran Berdasarkan Masalah. Surabaya:UNESA Press.

Iskandar. 2009. Penelitian Tindakan Kelas. Jakarta: Gaung Persada (GP) Press.

Kasihani Kasbolah. 2001. Penelitian Tindakan Kelas. Malang: Univesitas NegeriMalang.

Nana Sudjana. 2009. Dasar-Dasar Proses Belajar Mengajar. Bandung: SinarBaru Algensindo.

Oemar Hamalik. 2008. Belajar dan Teori Belajar. Jakarta: Bumi Aksara.

Sardiman A. M. 2004. Interaksi dan Motivasi Belajar Mengajar. Jakarta: RajaGrafindo Persada.

Sugiyanto. 2008. Model-model Pembelajaran Inovatif. Surakarta: PanitiaSertifikasi. 
Suharsimi Arikunto, Suhardjono, dan Supardi. Penelitian Tindakan Kelas.Jakarta: Penerbit Bumi Aksara.

Taufiq Amir. 2009. Inovasi Pendidikan Melalui Problem Based Learning. Jakarta:Kencana Prenada Media Group.

Trianto. 2009. Mendesain Model Pembelajaran Inovatif-Progresif. Jakarta:Prestasi Pustaka Publis. 